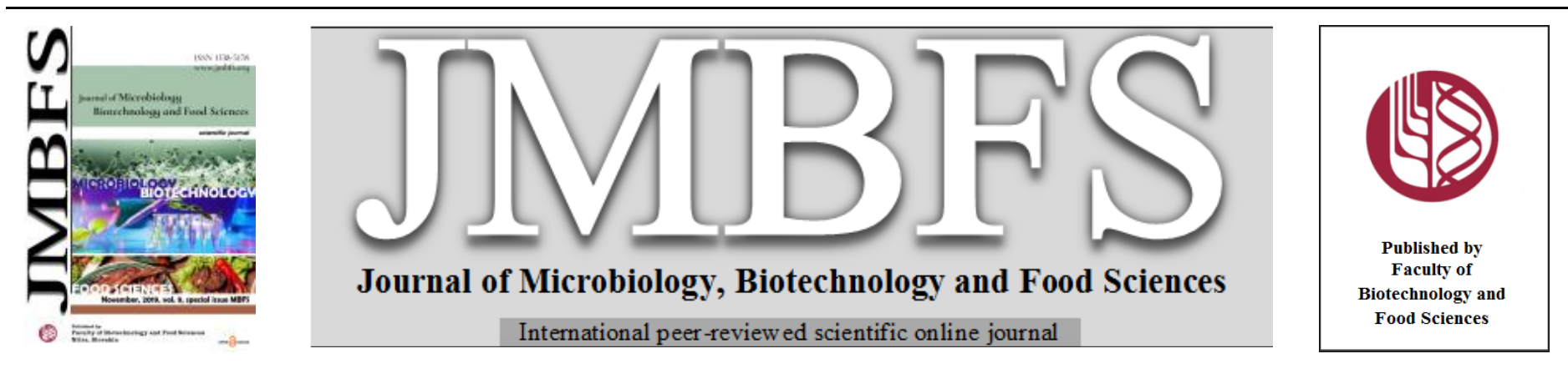

\title{
MICROFUNGI OF GRAPES FROM SMALL CARPATHIAN REGION IN SLOVAKIA
}

\author{
Soňa Felšöciová ${ }^{* 1}$, Miroslava Kačániová ${ }^{1}$ \\ Address(es): doc. Ing. Soňa Felšöciová,PhD \\ ${ }^{1}$ Slovak University of Agriculture in Nitra, Faculty of Biotechnology and Food Sciences, Department of Microbiology, Tr. A. Hlinku 2, 94976 Nitra, Slovak republic, \\ phone number: +4210376415813
}

*Corresponding author: sona.felsociova@uniag.sk

doi: 10.15414/jmbfs.2019.9.special.478-482

\section{ARTICLE INFO}

Received 10. 7. 2019

Revised 10. 10. 2019

Accepted 15. 10. 2019

Published 8. 11. 2019

Regular article OPEN $\partial_{\text {ACCESS }}$

\begin{abstract}
A total of 10 samples of grapes (bunches) without apparent fungal contamination were analyzed. The samples were collected during the 2017 and 2018 harvest from Suchá nad Parnou and Vrbové village in Small Carpathian region of Slovakia. Samples were sent to mycological laboratory, where they were stored at $4^{\circ} \mathrm{C}$ until their analysis. The objectives of this study were to gain more knowledge about mycobiota on grapes originating from Slovakia, with a focus on genus Penicillium and its ability to produce mycotoxins in in vitro conditions by thin layer chromatography method. For the isolation of fungi were used the direct plating technique on DRBC plates while surface sterilized grapes were used for endogenous mycobiota analysis. The plates were then incubated aerobically at $25 \pm 1{ }^{\circ} \mathrm{C}$ for one week in the dark. Overall, we isolated 818 strains belonging to 14 genera of filamentous microscopic fungi from surface mycobiota of grapes. The most frequent were genera Alternaria, Penicillium, Rhizopus, Sordaria, Aspergillus, Botrytis, Cladosporium and Epicoccum. The main occurring Penicillium species of the samples were P. expansum (60\% Isolation frequency, 93\% Relative density). A total of 388 isolates belonging to 12 genera were obtained from endogenous mycobiota. The most frequent and the most abundant genera were Alternaria, Cladosporium and Penicillium. From 3 different Penicillium species the most common was again P. expansum (30\% IF, 92.5\% RD). The selected isolates - P. citrinum, P. expansum, and $P$. chrysogenum were tested for their toxigenic ability. Out of 69 strains, $74 \%$ produced at least one mycotoxin as revealed by the method used here.
\end{abstract}

\section{INTRODUCTION}

The incidence of filamentous fungi and toxin levels in grapes and wines varies depending on the variety of grapes, the wine region, agricultural practices, weather conditions, the harvest and the winemaking process (Freire et al., 2017) The mycobiota frequently isolated from grapes includes the genera Aspergillus, Penicillium, Mucor, Rhizopus, Alternaria, Cladosporium, Botrytis and Fusarium (Trinidad et al., 2015).

Penicillium is a diverse fungal genus of ascomycetous fungi and contains more than 350 species (Visagie et al., 2014) playing various roles in natura ecosystems, agriculture, and biotechnology. Species of Penicillium are ubiquitous soil fungi, preferring cool and moderate climates commonly present in organic materials. Most of the species are saprophytes and live mainly on organic biodegradable substances (Kirk et al., 2008). Penicilli have a large economic impact on human life. They have two sides - a good and beneficial one and a bad and economically destructive one. Many species of Penicillium are of proven importance because of their widespread occurrence and ability to produce a wide range of bioactive metabolites, including antibacterial, antifungal, immune suppressants, cholesterol-lowering agents etc. (Petit et al., 2009). Some species produce toxins and may render food inedible or even dangerous (Visagie $\boldsymbol{e t}$ al., 2013). Penicillum expansum can cause rot in grapes, but does not usually attack grapes before harvest. Aside from losses in fruit, this species is regarded as the major producer of patulin, although this species produces many other toxic metabolites such as citrinin, roquefortine $\mathrm{C}$ or chaetoglobosins among others (Andersen et al., 2004).

Mycotoxins are secondary metabolities produced by filamentous fungi either preor postharvest and which can contaminate agricultural food and feed products and have detrimental effects on human and animal health. Much of the research on mycotoxins, including recent research on the effects of climate change on mycotoxins, has focused on Aspergillus, Fusarium, and Penicillium species, as they are the major mycotoxin-producing fungi in field crops and stored products in the world (Paris et al., 2015).
The most important mycotoxin in wine is ochratoxin A (OTA) (Amézqueta $\boldsymbol{e t}$ al., 2009; Varga and Kozakiewicz, 2006). The role of OTA producing penicillia in contaminating wine is of interest, although isolation from grapes is considered infrequent. However, Mikušová et al. (2010) isolated OTA-producing $P$. verrucosum from Slovakian grapes. Rousseaux et al. (2014) reported OTAproducing Penicillium species from grapes in northern Italy and France, suggesting they could be involved in OTA contamination. The production of OTA from Chinese penicillia (Zhang et al., 2016) requires confirmation (Perrone et al., 2017). In general, isolating OTA fungi from grapes should not exclude penicillia. The aim of our study was to monitor the mycobiota of grapes and determine the characteristic mycotoxin production profiles of Penicillium strains (patulin, citrinin, and roquefortin C) isolated from grapes for wine production in the Small Carpathian region of Slovakia.

\section{MATERIAL AND METHODS}

\section{Study area}

Grape samples were collected in moderate region of Slovakia, as it can be common in the Middle Europe areas, from Terra Parna winery, Suchá nad Parnou and from Sabo winery, Vrbové in Small Carpathian wine region during the years 2017 and 2018 (Table 1). Slovak republic has 6 distinct wine-growing zones (the Small Carpathians, the Southern Slovak, the Nitra, the Central Slovak, the Eastern Slovak and the Tokaj wine regions). They spread from the west to the east of the country along its southern and south-western borders. The largest in size and the most important over the centuries has been the Small Carpathian area (4260 ha of vineyards) spreads in the western of Slovakia (ÚKSÚP, 2019a). The Small Carpathian wine region is divided into 12 subregions. The subregion is the area with the same soil and climate conditions. Wine-growing zones are defined as geographic regions with distinct climatic conditions for grape cultivation (ÚKSÚP, 2019b). The Small Carpathian wine-growing region has medium climates and abundant moisture. 
Table 1 Wine grape varieties used in the study from the Small Carpathian region

\begin{tabular}{llccc}
\hline No of samVillage & Subregion & Grape variety & Date of harvest & Date of analyses \\
\hline 1. Suchá nad Parnou & Orešanský & Alibernet & 27.09 .2017 & 28.09 .2017 \\
2. Suchá nad Parnou & Orešanský & Blue Portugal & 27.09 .2017 & 28.09 .2017 \\
3. Suchá nad Parnou & Orešanský & Rheinriesling & 27.09 .2017 & 28.09 .2017 \\
4. Vrbové & Vrbovský & Pálava & 28.09 .2017 & 29.09 .2017 \\
5. Vrbové & Vrbovský & Dornfelder & 28.09 .2017 & 29.09 .2017 \\
6. Vrbové & Vrbovský & Alibernet & 04.09 .2018 & 05.09 .2018 \\
7. Vrbové & Vrbovský & Cabernet Sauvignon & 04.09 .2018 & 05.09 .2018 \\
8. Vrbové & Vrbovský & Dornfelder & 04.09 .2018 & 05.09 .2018 \\
9. Vrbové & Vrbovský & Pálava & 04.09 .2018 & 05.09 .2018 \\
10. Vrbové & Vrbovský & Chardonnay & 04.09 .2018 & 05.09 .2018 \\
\hline
\end{tabular}

\section{Sampling}

Two samples of red grapes (Alibernet, Blue Portugal) and one sample of white grape (Rheinriesling) were collected from Suchá nad Parnou and one sample of white grape (Pálava) and one sample of red grape (Dornfelder) were collected from Vrbové in the final stages of maturation of the berries (harvest season), at the end of September, 2017.

Three samples of red grapes (Alibernet, Cabernet Sauvignon and Dornfelder) and two samples of white grapes (Pálava and Chardonnay) were collected from Vrbove at the beginning of September, 2018. The sample comprised 3 bunches of grapes collected across two diagonal transects. Grape samples were put directly each into a sterile plastic bag. Samples were brought into the laboratory and kept at $5{ }^{\circ} \mathrm{C}$ till fungal analysis.

\section{Mycological analysis of grapes}

A total of 50 berries ( $7-8$ berries per bunch) from each sample were plated in Dichloran Rose Bengal Chloramphenicol agar medium (DRBC) and incubated a $25 \pm 1{ }^{\circ} \mathrm{C}$ in the dark for one week. In this way was determined an exogenous mycobiota. Another 50 grapes were surface-disinfected in $1 \% \mathrm{NaClO}$ for $1 \mathrm{~min}$ according methods of Magnoli $\boldsymbol{e t} \mathbf{a l}$. (2003) and 3 times rinsed by submersion in sterile distilled water (total amount $1 \mathrm{~L}$ ) to remove incidental surface contaminants, dried, plated in the same medium and incubated at $25{ }^{\circ} \mathrm{C}$ in the dark for 7 days. In this way was determined an endogenous mycobiota. The identification of fungal taxa was based on macroscopic and microscopic features, with guidelines by Pitt and Hocking (2009). Penicillium strains were isolated and cultivated on MEA (Malt extract agar) (Samson et al., 2010), CYA (Czapek yeast agar) (Samson et al., 2010), Creatine-Sucrose agar (CREA) (Samson et al., 2010) and Yeast Extract agar (YES) (Samson et al., 2010). From the pure cultures, genus Penicillium was identified to species level based on macroscopic and microscopic characteristics according to the manuals of Pitt and Hocking (2009), Samson and Frisvad (2004) and Samson et al. (2002a, 2010).

\section{Results evaluation}

The obtained results were evaluated and expressed according to isolation frequency (IF) and relative density (RD). The isolation frequency (\%) is defined as the percentage of samples within which the species or genus occurred at least once. The relative density (\%) is defined as the percentage of isolates of the species or genus, occurring in the analyzed sample (Guatam et al., 2009). These values were calculated according to González et al. (1999) as follows: $\operatorname{IF}(\%)=(\mathrm{ns} / \mathrm{N}) \times 100 ; \mathrm{RD}(\%)=(\mathrm{ni} / \mathrm{Ni}) \times 100$

$\mathrm{ns}-$ number of samples with a species or genus; $\mathrm{N}$ - total number of samples; $\mathrm{ni}$ - number of isolates of a species or genus; $\mathrm{Ni}$ - total number of isolated fungi.

\section{Toxinogenity analysis}

Toxinogenity of selected isolates was screened in in vitro conditions by means of thin layer chromatography (TLC) according to Samson et al. (2002b), modified by Labuda and Tančinová (2006). Extracellular metabolites - citrinin and patulin were carried out on YES agar and intracellular roquefortin C on CYA agar. A few plugs of mycelium were removed from different points of the colony in an Eppendorf tube with $500 \mu \mathrm{L}$ of chloroform:methanol - 2:1 (Reachem, Slovak Republic). The content of the tubes was stirred for $5 \mathrm{~min}$ by Vortex Genie ® 2 (MO BIO Laboratories, Inc. - Carlsbad, CA, USA). The volume $30 \mu \mathrm{L}$ of liquid phase of extracts along with $10 \mu \mathrm{L}$ of standards (Sigma, Germany) was applied on TLC plate (Alugram ${ }^{\circledR}$ SIL G, Macherey - Nagel, Germany). The plate was put into TEF solvent (toluene:ethyl acetate:formic acid - 5:4:1, toluene - Mikrochem, Slovak Republic; ethyl acetate and formic acid - Slavus, Slovak Republic). After elution the plate was air-dried. Identification of the metabolites was done by comparison with metabolite standards. Roquefortin $\mathrm{C}$ was visible after spraying with $\mathrm{Ce}\left(\mathrm{SO}_{4}\right)_{2} \times 4 \mathrm{H}_{2} \mathrm{O}$ as an orange spot. Patulin detection was achieved by spraying with $0.5 \%$ methylbenzothiazolone hydrochloride (MBTH) (Merck, Germany) in methanol and heating at $130{ }^{\circ} \mathrm{C}$ for $8 \mathrm{~min}$ and then detected as a yellow-orange spot under visible light. Citrinin was detected directly as an intense yellow-green streak under ultraviolet light $(365 \mathrm{~nm})$.

\section{RESULTS AND DISCUSSION}

The filamentous fungi identified in 4 white and 6 red grape varieties from surface mycobiota during the years 2017 and 2018 are indicated in table 2. A total of 818 strains belonging to 14 genera were identified. From varieties Alibernet (1), Blue Portugal (2) and Rheinriesling (3) from Suchá nad Parnou in 2017, the highest number of isolates (from 89 to 102) with 8 or 9 genera were found. All samples were colonised by genera Alternaria, Aspergillus, Cladosporium, Epicoccum and Penicillium, concretely $P$. expansum.

Table 2 Fungi identified in Slovak wine grapes from exogenous mycobiota from 2017 to 2018 by the direct plating method

\begin{tabular}{lllllllllll}
\hline Fungal taxa & $\mathbf{1 .}$ & $\mathbf{2 .}$ & $\mathbf{3 .}$ & $\mathbf{4 .}$ & $\mathbf{5 .}$ & $\mathbf{6 .}$ & $\mathbf{7 .}$ & $\mathbf{8 .}$ & $\mathbf{9 .}$ & $\mathbf{1 0 .}$ \\
\hline Alternaria & 36 & 16 & 7 & 35 & 9 & 93 & 90 & 70 & 54 & 73 \\
Arthrinium & 3 & - & 2 & 2 & - & - & - & - & - & - \\
Aspergillus & 3 & 4 & 1 & 1 & - & 1 & 1 & - & - & - \\
Aureobasidium & - & - & - & - & - & - & - & - & 1 & - \\
Botrytis & 2 & 6 & - & 1 & 1 & - & - & 2 & - & 12 \\
Cladosporium & 19 & 13 & 31 & 2 & - & - & - & - & - & 2 \\
Epicoccum & 8 & 12 & 20 & - & - & 1 & 2 & - & - & - \\
Eurotium & 6 & - & - & - & - & - & - & - & - & - \\
Fusarium & 6 & - & - & 2 & 2 & - & - & - & - & - \\
Mucor & - & 3 & - & 8 & - & - & - & - & - & - \\
Penicillium & 19 & 29 & 29 & 2 & 4 & 1 & 3 & - & - & 1 \\
P. aurantiogriseum & - & - & - & - & 1 & - & - & - & - & - \\
P. brevicompactum & - & - & - & - & 1 & - & - & - & - & - \\
P. citrinum & - & - & - & - & - & - & 3 & - & - & - \\
P. expansum & 19 & 29 & 29 & 2 & 2 & - & - & - & - & 1 \\
P. glabrum & - & - & - & - & - & 1 & - & - & - & - \\
Rhizopus & - & 4 & 7 & 5 & - & 4 & 4 & 7 & 5 & 2 \\
Sordaria & - & 2 & 4 & 5 & - & 9 & 4 & & 1 & 2 \\
Trichoderma & - & - & - & 1 & - & & & & \\
$\sum$ & 102 & 89 & 101 & 64 & 16 & 109 & 104 & 79 & 61 & 93 \\
\hline Legend: 1, 6 - Alibernet, 2 - Blue Portugal, 3- Rheinriesling, 4,9-Pálava, 5,8- Dornfelder, 7-Cabernet Sauvignon, 10-Chardonnay &
\end{tabular}

The lower number of isolates (64) were isolated from the white variety Pálava (4) from Vrbové in 2017 but on the other hand with the highest number of genera (11). The least isolates and genera of filamentous microscopic fungi were isolated from the red grape variety Dornfelder (5) from Vrbové in 2017. In 2018, the red grape varieties Alibernet (6), Cabernet Sauvignon (7) and the white variety Chardonnay (10) reached approximately the same quantitative and qualitative representation of micromycetes from Vrbové with the dominance of the genus Alternaria. The lowest quantitative and qualitative representation of 
micromycetes was isolated from the Pálava (9) and Dornfelder (8) varieties again with the dominance of the genus Alternaria.

Alternaria spp. are ubiquitous plant pathogens that may invade fruit (Asam et al., 2010). Fungal contamination of grapes could occur before or during harvest and processing (Prendes et al., 2016). Globally, Alternaria has been isolated from grapes, musts, wines, and raisins. Alternaria cause rot bunch of damaged berries, scrape and pedicels (Kakalíková et al., 2009; Steel et al., 2013). The exposure to Alternaria toxins has been linked to a great variety of adverse effects to both human and animal health (Dall'Asta et al., 2014). There are not specific international regulations of Alternaria toxins in food (Trinidad et al., 2015).

Without surface disinfection, a total of 388 strains belonging to 12 genera were identified during the years 2017 and 2018, while Alternaria colonised all the samples examined (Table 3). In 2018, we isolated a lower number of genera from our tested samples (from 2 to 4) than in 2017 (from 3 to 8). Species Penicillium expansum were dominated from the samples of Terra Parna (1-3) in 2017. In 2018, P. expansum was not detected. The occurrence of Penicillium spp. in other samples was generally low. The highest number of isolates was detected in the genus Alternaria (53) in the grape variety Pálava (4), however in most samples it was dominated.

Table 3 Fungi identified in Slovak wine grapes from endogenous mycobiota from 2017 to 2018 by the direct plating method

\begin{tabular}{lllllllllll}
\hline Fungal taxa & $\mathbf{1 .}$ & $\mathbf{2 .}$ & $\mathbf{3 .}$ & $\mathbf{4 .}$ & $\mathbf{5 .}$ & $\mathbf{6 .}$ & $\mathbf{7 .}$ & $\mathbf{8 .}$ & $\mathbf{9 .}$ & $\mathbf{1 0 .}$ \\
\hline Alternaria & 7 & 15 & 8 & 53 & 10 & 37 & 41 & 45 & 11 & 25 \\
Arthrinium & 6 & 2 & 3 & 1 & - & - & - & - & - & - \\
Aspergillus & - & - & - & - & 1 & - & - & - & - & - \\
Botrytis & - & 1 & 2 & 9 & - & - & - & - & - & 1 \\
Cladosporium & 9 & 11 & 18 & - & 1 & 2 & 2 & 5 & 2 & - \\
Epicoccum & 3 & 1 & - & - & - & - & 1 & - & - & - \\
Fusarium & - & 1 & - & - & - & - & - & - & - & - \\
Rhizopus & - & - & - & 1 & - & & & 3 & 1 & - \\
Penicillium & 10 & 2 & 25 & - & - & 1 & 4 & - & - & - \\
$\quad$ P. citrinum & - & - & - & - & - & - & 3 & - & - & - \\
$\quad$ P. expansum & 10 & 2 & 25 & - & - & - & - & - & - & - \\
$\quad$ P. chrysogenum & - & - & - & - & - & 1 & 1 & - & - & - \\
Sordaria & 1 & 1 & - & 1 & - & - & - & - & - & - \\
Talaromyces & - & - & - & 2 & - & - & - & - & - & - \\
Trichoderma & - & - & - & 2 & - & - & - & - & - & - \\
$\sum$ & 36 & 34 & 56 & 69 & 12 & 40 & 48 & 53 & 14 & 26 \\
\hline
\end{tabular}

Legend: 1, 6 - Alibernet, 2 - Blue Portugal, 3 - Rheinriesling, 4, 9 - Pálava, 5, 8 Dornfelder, 7 - Cabernet Sauvignon, 10 - Chardonnay

Data in table 4 show that, fourteen fungal genera namely Alternaria, Arthrinium, Aspergillus, Aureobasidium, Botrytis, Cladosporium, Epicoccum, Eurotium Fusarium, Mucor, Penicillium, Rhizopus, Sordaria and Trichoderma were identified from fresh grape samples. Alternaria was the most frequently occurring genus $(100 \%)$, followed by Penicillium, Rhizopus (80\%, each), Sordaria (70\%), Aspergillus, Botrytis (60\%, each), Cladosporium and Epicoccum (50\%, each). The most abundant genus from exogenous mycobiota was Alternaria (59\%), followed by Penicillium (11\%), Cladosporium (8\%),
Epicoccum and Rhizopus (5\%, each) of all the fungi found. The remaining genera were detected in less than $5 \%$ of all the isolates. From 5 different Penicillium species the most frequent and most abundant was $P$. expansum. Alternaria is the main component of wine grape mycobiota from different winemaking regions worldwide (Magnoli et al., 2003; Rousseaux et al., 2014; Prendes et al., 2015; Tančinová et al., 2015). Alternaria growth on grapes has been reported in several countries such as Argentina, Brazil, Spain, Italy, Portugal, USA, Slovakia, Hungary and Czech Republic. The incidence of Alternaria in grapes has been reported in different percentages with respect to total mycobiota: 5-23\% in USA, $25 \%$ in Italy, $80 \%$ in Argentina, 3-18\%, 24\%, 17\% in different studies in Portugal, 75\%, 3-58\%, 13\% in Spain, and A. alternata and A. tenuissima were reported in 16-19\% in Slovakia (Prendes et al., 2016).

From the twelve vineyards in the Small Carpathian area were collected 14 samples of wine grapes (white 6, red 8) during harvesting 2011, 2012 and 2013 (Felšöciová $\boldsymbol{e t}$ al., 2015c). In these samples were identified 22 genera and $79 \%$ of samples were colonized by the genus Aspergillus. During the survey, 37 isolates belonging to 7 Aspergillus species (A. clavatus, A. flavus, A. section Nigri, A ostianus, A. parasiticus, A. versicolor and A. westerdijkiae) were isolated and identified from exogenous mycobiota. The main occurring aspergillus species of the samples were A. section Nigri (64\%). Black aspergilli have been reported as the predominant fungi from Spanish wine and liqueur grapes at harvesting time, constituting from $88.7 \%$ to $98.5 \%$ of the total Aspergillus isolates (Bau et al. 2005, 2006; Gómez et al., 2006). In our research Aspergillus isolates were found in grape samples but with low relative density $(1 \%)$.

By the endogenous (surface-disinfected) plating method were identified 12 different genera from the 388 fungal strains (Table 4): Alternaria, Arthrinium, Aspergillus, Botrytis, Cladosporium, Epicoccum, Fusarium, Penicillium, Rhizopus, Sordaria, Talaromyces and Trichoderma. Data in the same table showed, that Alternaria was the most frequently occurring genus (100\%), followed by Cladosporium ( $80 \%$ ) and Penicillium (50\%). The 3 most abundant genera found by descending order and with the highest relative density were Alternaria (65\%), Cladosporium (13\%) and Penicillium (11\%). From 3 different Penicillium species the most common in grape samples was again $P$. expansum. Felšöciová et al. (2015a) investigated an endogenous mycobiota of grapes from Eastern wine region of Slovakia. A total of 582 isolates were obtained that belonged to 10 genera: Alternaria, Aspergillus, Botrytis, Cladosporium, Epicoccum, Fusarium, Mucor, Penicillium, Rhizopus, and Trichoderma. The most frequent were 4 genera Alternaria, Aspergillus, Botrytis and Penicillium with $100 \%$ frequention. The relative density of genera Alternaria, Cladosporium and Penicillium, were the highest $(42 \%, 19.6 \%$ and $15.8 \%$, respectively) as in our results. Frequency of isolation of Penicillium spp. in Spanish vineyards was low (Bau et al., 2005, 2006; Bellí et al., 2006; Gómez et al., 2006). In other surveys made in European vineyards with different climatic conditions, Penicillium was the predominant genus (Abrunhosa et al., 2001; Serra et al., 2005, 2006) Penicillium expansum, the responsible agent of blue mould on fruits, has been reported in grapes in different studies (Abrunhosa et al., 2001; Serra et al., 2005, 2006; Felšöciová and Kačániová, 2019).

Table 4 The occurrence, isolation frequency and relative density of filamentous microscopic fungi in exogenous and endogenous mycobiota of grapes $(n=10)$ harvested in Small Carpathian wine region

\begin{tabular}{|c|c|c|c|c|c|c|}
\hline Fungal taxa & $\begin{array}{l}\text { No of isolates } \\
\text { exo }\end{array}$ & $\begin{array}{l}\text { Isolation } \\
\text { frequency }(\%)\end{array}$ & $\begin{array}{l}\text { Relative } \\
\text { density }(\%)\end{array}$ & $\begin{array}{l}\text { No of isolates } \\
\text { endo }\end{array}$ & $\begin{array}{l}\text { Isolation } \\
\text { frequency }(\%)\end{array}$ & $\begin{array}{l}\text { Relative } \\
\text { density }(\%)\end{array}$ \\
\hline Alternaria & 483 & 100 & 59 & 252 & 100 & 65 \\
\hline Arthrinium & 7 & 30 & 0.9 & 12 & 40 & 3 \\
\hline Aspergillus & 11 & 60 & 1 & 1 & 10 & 0.3 \\
\hline Aureobasidium & 1 & 10 & 0.1 & - & - & - \\
\hline Botrytis & 24 & 60 & 3 & 13 & 40 & 3 \\
\hline Cladosporium & 67 & 50 & 8 & 50 & 80 & 13 \\
\hline Epicoccum & 43 & 50 & 5 & 5 & 30 & 1 \\
\hline Eurotium & 6 & 10 & 0.7 & - & - & - \\
\hline Fusarium & 10 & 30 & 1 & 1 & 10 & 0.3 \\
\hline Mucor & 11 & 20 & 1 & - & - & - \\
\hline Penicillium & 88 & 80 & 11 & 42 & 50 & 11 \\
\hline P. aurantiogriseum & 1 & 10 & - & - & - & - \\
\hline P. brevicompactum & 1 & 10 & - & - & - & - \\
\hline P. citrinum & 3 & 10 & - & 3 & 10 & - \\
\hline P. expansum & 82 & 60 & - & 37 & 30 & - \\
\hline P. glabrum & 1 & 10 & - & - & - & - \\
\hline P. chrysogenum & - & - & - & 2 & 20 & 0.5 \\
\hline Rhizopus & 38 & 80 & 5 & 5 & 30 & 1 \\
\hline Sordaria & 27 & 70 & 3 & 3 & 30 & 0.8 \\
\hline Talaromyces & - & - & - & 2 & 10 & 0.5 \\
\hline Trichoderma & 2 & 20 & 0.2 & 2 & 10 & 0.5 \\
\hline Total & 818 & & & 388 & & \\
\hline
\end{tabular}

Legend: No - number of isolated micromycetes from exogenous mycobiota/ from endogenous mycobiota 
The toxigenic profile of the 69 Penicillium isolates representing $P$. citrinum, $P$. expansum and $P$. chrysogenum from the Slovak grapes is shown in Table 5. Patulin, citrinin and roquefortin $\mathrm{C}$ production was tested by thin layer chromatography method in in vitro condition. Almost all the isolates were able to produce mycotoxins. From the exogenous mycobiota 44 strains were tested, namely $P$. citrinum and $P$. expansum. Positive toxigenity was detected for citrinin by $P$. citrinum and $P$. expansum, for roquefortin $\mathrm{C}$ by $P$. expansum and 35 strain out of 41 screened produced patulin. From the endogenous mycobiota 25 strains were tested, namely $P$. citrinum, $P$. expansum and $P$. chrysogenum. Positive toxigenity was detected for citrinin and roquefortin $C$ by $P$. expansum $(100 \%$, each) and 10 strains out of 21 produced patulin. All tested strains of $P$. citrinum were positive for citrinin and one strain of $P$. chrysogenum did not produce roquefortin $\mathrm{C}$. Out of 69 strains, $74 \%$ produced at least one mycotoxin as revealed by the method used here.

Table 5 Toxinogenity of selected Penicillium strains, isolated from exogenous and endogenous mycobiota of wine grapes

\begin{tabular}{|c|c|c|c|}
\hline Penicillium species & patulin & citrinin & roquefortin $\mathrm{C}$ \\
\hline \multicolumn{4}{|c|}{ Toxinogenity of exogenous mycobiota } \\
\hline P. citrinum & nt & $3 * / 3 * *$ & nt \\
\hline P. expansum & $35 / 41$ & $41 / 41$ & $41 / 41$ \\
\hline \multicolumn{4}{|c|}{ Toxinogenity of endogenous mycobiota } \\
\hline P. citrinum & nt & $3 / 3$ & nt \\
\hline P. expansum & $10 / 21$ & $21 / 21$ & $21 / 21$ \\
\hline P. chrysogenum & nt & nt & $0 / 1$ \\
\hline
\end{tabular}

Patulin is a tetraketide lactone produced by a variety of moulds, in particular, Aspergillus, Penicillium, and Byssochlamys species (Puel et al., 2010). The main producer of patulin is Penicillium expansum, which contaminates mainly apple and apple products, and also other fruits like cherries, blueberries, plums, bananas, strawberries, and grapes, processed grape juice and fermenting wine (Abrunhosa et al., 2001). Penicillium expansum is found frequently in botrytized grapes (Russell et al., 2018). The occurrence of patulin in wine is low because it is well-known to be degraded partially by the fermentation process (Moss and Long, 2002). Patulin is thermal resistant, causes gastrointestinal problems, including ulceration, distension and bleeding, skin rashes, and is known to be mutagenic, immunotoxic, and neurotoxic mycotoxin (Medina et al., 2005). Patulin is known to be antibacterial, cytotoxic and perhaps even anticarcinogenic (Kumar et al., 2018). It is classified in group 3 as not classifiable as to its carcinogenicity to human by IARC (Varga et al., 2015). Out of 62 screened strains in our research, $73 \%$ produced patulin. The predominant Penicillium species was not only Penicillium expansum as in our study, but also Penicillium chrysogenum (100\%) from Tokaj wine region (Felšöciová et al., 2015b) Penicillium expansum produced patulin (15 out of 18 strains screened), citrinin (13 out of 18 strains screened) and all of them produced roquefortin $\mathrm{C}$.

Citrinin is a pentaketide derivate produced principally by species of the genera Penicillium and Aspergillus (A. terreus, A. niveus). Penicillium citrinum, the main producer of citrinin, has been isolated from grapes, $P$. expansum could produce this mycotoxin, too. Citrinin, a hepato-nephrotoxic compound, is not degraded during alcoholic fermentation and may be present in very small amounts in wine (Samson et al., 2011). All 68 tested strains were positive on citrinin in our study. The metabolite citrinin, a characteristic yellow-lemon pigment, was also produced by all strains of $P$. expansum from grapes and must under laboratory conditions in Small Carpathian wine growing region of Slovakia in the year 2017 (Felšöciová et al., 2018).

Roquefortin $\mathrm{C}$ is the most widespread mycotoxin produced by various fungi, particularly species from the Penicillium genus, and is known as an importan neurotoxic (paralytic) secondary metabolite (Cole and Cox, 1981). Out of 63 tested strains, $98 \%$ produced roquefortin C. A total of 10 wine producing grapes were collected from the Central Slovak region in 2011 and 2012, which involved 7 vineyards (Felšöciová et al., 2014). Twenty five potentially toxigenic species were tested for their toxigenic ability on roquefortin C, namely $P$. crustosum, $P$. expansum, $P$. griseofulvum, $P$. chrysogenum and $P$. hordei. Positive toxinogenity was also high, $92 \%$ strains produced mentioned mycotoxin. Felšöciová et al. (2015c) also tested 68 Penicillium strains on roquefortine $\mathrm{C}$ from Smal Carpathian winemaking region from exogenous mycobiota of grapes which all were positive.

\section{CONCLUSION}

From 10 samples of wine grapes from exogenous and endogenous mycobiota were isolated 1206 strains belonging to 15 genera. Alternaria, Cladosporium and Penicillium were the most common genera within the surface and endogenous colonisation. The most abundant genus was Alternaria almost in all samples. During the survey six Penicillium species were isolated: $P$. aurantiogriseum, $P$. brevicompactum, $P$. citrinum, $P$. expansum, $P$. glabrum and $P$. chrysogenum. Of the 130 fungi of the Penicillium genus isolated from grapes, $119(91 \%)$ were $P$. expansum, which shows a higher risk of the toxin in grapes and their derivatives from the region. The present work showed the toxigenic potential of the Penicillium species isolated from wine grapes, which indicates the potential risk of mycotoxin accumulation in the fruits. Extracts of fungal strains were analysed for patulin, citrinin and roquefortin $\mathrm{C}$ by thin-layer chromatography. Patulin was produced by $73 \%(45 / 62)$, citrinin was produced by $100 \%(68 / 68)$, roquefortin C production was observed in $98 \%$ (62/63). Our results showed that the Penicillium species commonly isolated from grapes are a source of the mycotoxins patulin, citrinin and roquefortin $\mathrm{C}$. Altogether, these results indicate that the higher presence of potentially toxigenic genera Alternaria and Penicillium in wine grapes could represent a risk in the health of wine consumers

Acknowledgments: This work has been supported by grants of the European Community of project No. 26220220180: Building Research Centre "AgroBioTech" and of Slovak Research and Development Agency VEGA No. 1/0411/17 and KEGA 015SPU-4/2018.

\section{REFERENCES}

ABRUNHOSA, L., PATERSON, R. R. M., KOZAKIEWICZ, Z., LIMA, N., VENÂNCIO, A. 2001. Mycotoxin production from fungi isolated from grapes. Lett Appl Microbiol, 32(4), 240-242. https://doi.org/10.1046/j.1472765x.2001.00897.x

AMÉZQUETA, S., GONZÁLEZ-PEÑAS, E., MURILLO-ARBIZU, M., LÓPEZ DE CERAIN, A. 2009. Ochratoxin A decontamination: A review. Food Control, 20(4), 326-333. https://doi.org/10.1016/j.foodcont.2008.05.017

ANDERSEN, B., SMEDSGAARD, J., FRISVAD, J. C. 2004. Penicillium expansum: consistent production of patulin, chaetoglobosins and other secondary metabolites in culture and their natural occurrence in fruit products. J. Agric. Food Chem., 52(8), 2421-8. https://doi.org/10.1021/jf035406k

ASAM, S., KONITZER, K., RYCHLIK, M. 2010. Precise determination of the Alternaria mycotoxins alternariol and alternariol monomethyl ether in cereal, fruit and vegetable products using stable isotope dilution assays. Mycotoxin Research, 27(1), 23-28. https://doi.org/10.1007/s12550-010-0071-6

BAU, M., BRAGUlAT, M., ABARCA, M., MINGUEZ, S., CABAÑES, F. 2005. Ochratoxigenic species from Spanish wine grapes. Int J Food Microbiol., 98(2), 125-130. https://doi.org/10.1016/j.ijfoodmicro.2004.05.015

BAU, M., BRAGULAT, M. R., ABARCA, M. L., MINGUEZ, S., CABAÑES, F. J. 2006. Ochratoxin A producing fungi from Spanish vineyards. In HOCKING, A. D., PITT, J. I., SAMSON, R. A., THRANE, U. Advances in Food Mycology. Advances in Experimental Medicine and Biology. New York : Springer, 173179. https://doi.org/10.1007/0-387-28391-9 10

BELLÍ, N., BAU, M., MARÍN, S., ABARCA, M., RAMOS, A., BRAGULAT, M. 2006. Mycobiota and ochratoxin A producing fungi from Spanish wine grapes. Int $J \quad$ Food Microbiol., $111, \quad 40-45$ https://doi.org/10.1016/j.ijfoodmicro.2006.03.011

COLE, R. J., COX, R. H. 1981. Handbook of Toxic Fungal Metabolites. New York : Academic Press, 937 p. ISBN : 0121797600 https://doi.org/10.1016/c2009-0-03073-6

DAll'ASTA, C., CIRLINI, M., FALAVIGNA, C. 2014. Mycotoxins from Alternaria: toxicological implications. In FISHBEIN, C., HEILMAN, J. M. ed Advances in Molecular Toxicology. Amsterdam : Elsevier B.V., 107- 121. https://doi.org/10.1016/b978-0-444-63406-1.00003-9

FELŠÖCIOVÁ S., KAČÁNIOVÁ, M. 2019. Mycobiota in traditional grapes and grape for ice wine production cultivated in Slovakia. Scientific Papers: Animal Science and Biotechnologies, 52(1), 70-77.

FELŠÖCIOVÁ, S., MAŠKOVÁ, Z., KAČÁNIOVÁ, M. 2018. Fungal diversity in the grapes-to-wines chain with emphasis on Penicillium species. Potravinarstvo, 12(1), 379-386. https://doi.org/10.5219/882

FELŠÖCIOVÁ, S., RYBÁRIK, L', TANČINOVÁ, D., MAŠKOVÁ, Z., KAČÁNIOVÁ, M. 2014. Penicillium strains isolated from grapes grown in the Central Slovak wine region. Journal of Microbiology, Biotechnology and Food Sciences, 3(1), 210-214.

FELŠÖCIOVÁ, S., RYBÁRIK, L', TANČINOVÁ, D., MAŠKOVÁ, Z. KAČ́AIOVÁ, M. 2015a. Microfungi and mycotoxins of grapes from Eastern Slovak wine region. Journal of Microbiology, Biotechnology and Food Sciences, 4(1), 12-15. https://doi.org/10.15414/jmbfs.2015.4.special1.12-15

FELŠÖCIOVÁ, S., RYBÁRIK, L', TANČINOVÁ, D., MAŠKOVÁ, Z. KAČÁNIOVÁ, M. 2015b. Microfungi and mycotoxins of grapes from Tokaj wine region. Journal of Microbiology, Biotechnology and Food Sciences, 4(1), 16-18. https://doi.org/10.15414/jmbfs.2015.4.special1.16-18

FELŠÖCIOVÁ, S., TANČINOVÁ, D., RYBÁRIK, L., MAŠKOVÁ, Z., KAČ́ANIOVÁ, M. 2015c. Mycobiota of Slovak wine grapes with emphasis on Aspergillus and Penicillium species in the Small carpathian area. Potravinarstvo, 9(1), 501-508. https://doi.org/10.5219/529

FREIRE, L., PASSAMANI, F. R. F., THOMAS, A. B., NASSUR, R. D. M. R., SILVA, L. M., PASCHOAL, F. N., PEREIRA, G. E., PRADO, G., BATISTA, L. R. 2017. Influence of physical and chemical characteristics of wine grapes on the incidence of Penicillium and Aspergillus fungi in grapes and ochratoxin A in wines. International journal of food microbiology, 241, 181-190. https://doi.org/10.1016/j.ijfoodmicro.2016.10.027 
GÓMEZ, C., BRAGULAT, M., ABARCA, M., MÍNGUEZ, S., CABAÑES, F. 2006. Ochratoxin A-producing fungi from grapes intended for liqueur wine production. Food $\quad$ Microbiol., $\quad$ 23(6), 541-545. https://doi.org/10.1016/j.fm.2005.09.007

GONZÁLEZ, H. H. L., MARTÍNEZ, E. J., PACIN, A., RESNIK, S. L. 1999. Relationship between Fusarium graminearum and Alternaria alternate contamination and deoxinivalenol occurrence on Argentinian durum wheat Mycopathologia, 144(2), 97-102. http://dx.doi.org/10.1023/a:1007020822134 GUATAM, A., SHARMA, S., BHADAURIA, R. 2009. Detection of toxigenic fungi and mycotoxins in medicinally important powdered herbal drugs. The Internet Journal of Microbiology, 7(2), 1-8. http://dx.doi.org/10.5580/104b KAKALÍKOVÁ, L., JANKURA, E., ŠROBÁROVÁ, A. 2009. First report of Alternaria bunch rot of grapevines in Slovakia. Australas Plant Dis Notes, 4, 6869.

KIRK, P. M., CANNON, P. F., DAVID, J. C., STALPERS, J. A. 2008 Ainsworth and Bisby's Dictionary of the Fungi (10th edition). Wallingford, UK, CT : CABI, 771 p. $\quad$ ISBN: 978 0 $85199 \quad 826 \quad 8$ https://doi.org/10.1108/09504120910969104

KUMAR, A., ASTHANA, M., GUPTA, A., NIGAM, D., MAHAJAN, S. 2018 Secondary metabolism and antimicrobial metabolites of Penicillium. In GUPTA V., RODRIGUEZ-COUTO, S. ed. New and future developments in microbial biotechnology and bioengineering, Penicillium system properties and applications. Netherlands, UK, US : Elsevier, 47-68. ISBN: 978-0-444-63501-3. https://doi.org/10.1016/b978-0-444-63501-3.00003-x

LABUDA, R., TANČINOVÁ, D. 2006. Fungi recovered from Slovakian poultry feed mixtures and their toxinogenity. Annals of Agricultural and Environmental Medicine, 13(2), 193-200.

MAGNOLI, C., VIOLANTE, M., COMBINA, M., PALACIO, G., DALCERO, A. 2003. Mycoflora and ochratoxin-producing strains of Aspergillus section Nigr in wine grapes in Argentina. Letters in Applied Microbiology, 37(2), 179-184. http://dx.doi.org/10.1046/j.1472765x.2003.01376.x

MEDINA, A., MATEO, R., LÓPEZ-OCAÑA, L., VALLE-ALGARRA, F., JIMÉNEZ, M. 2005. Study of Spanish Grape Mycobiota and ochratoxin A production by isolates of Aspergillus tubingensis and other members of Aspergillus section Nigri. Applied and Environmental Microbiology. 71(8), 4696-4702. https://doi.org/10.1128/aem.71.8.4696-4702.2005

MIKUŠOVÁ, P., RITIENI, A., SANTINI, A., JUHASOVÁ, G., ŠROBÁROVÁ, A. 2010. Contamination by moulds of grape berries in Slovakia. Food Additives $\begin{array}{llll}\text { \& Contaminants: } \quad \text { Part } & \text { A, 27(5), } & \text { 738-747. }\end{array}$ https://doi.org/10.1080/19440040903571754

MOSS, M. O., LONG, M. T. 2002. Fate of patulin in the presence of the yeast Saccharomyces cerevisiae. Food Additives and Contaminants, 19(4), 387-399. https://doi.org/10.1080/02652030110091163

PARIS, K., PAULA, M., YIN-JUNG, L., NAHRER, K., BINDER, E. M. 2015.7 Climate change impacts on mycotoxin production. In BOTANA, L. M., SAINZ, M. J. ed. Climate Change and Mycotoxins, 133-152. ISBN 978-3-11-033361-9. https://doi.org/10.1515/9783110333619-009

PERRONE, G., LOGRIECO, A. F., FRISVAD, J. C. 2017. Comments on "Screening and identification of novel ochratoxin A-producing fungi from grapes. Reporting Ochratoxin A production from strains of Aspergillus, Penicillium and Talaromyces. Toxins, 9(2), 65. https://doi.org/10.3390/toxins9020065

PETIT, P., LUCAS, E. M. F., ABREU, L. M., PFENNING, L. H., TAKAHASHI, J. A. 2009. Novel antimicrobial secondary metabolites from a Penicillium sp. isolated from Brazilian cerrado soil. Electronic Journal of Biotechnology, 12(4), 1-9. https://doi.org/10.2225/vol12-issue4-fulltext-9 PITT, J. I., HOCKING, A. D. 2009. Fungi and food spoilage. $3^{\text {rd }}$ ed. London, New York : Springer Science + Business Media, LLC, 519 p. ISBN 978 0-38792206-5. http://dx.doi.org/10.1016/j.ijfoodmicro.2010.08.005

PRENDES, L. P., MERÍN, M. G., ANDREONI, M. A., RAMIREZ, M. L., MORATA DE AMBROSINI, V. I. 2015. Mycobiota and toxicogenic Alternaria spp. strains in Malbec wine grapes from DOC San Rafael, Mendoza, Argentina. Food Control, 57, 122- 128. https://doi.org/10.1016/j.foodcont.2015.03.041 PRENDES, L. P., ZACHETTI, V. G. L., PEREYRA, A., MORATA DE AMBROSINI, V. I., RAMIREZ, M. L. 2016. Water activity and temperature effects on growth and mycotoxin production by Alternaria alternata strains isolated from Malbec wine grapes. Journal of Applied Microbiology, 122(2), 481-492. https://doi.org/10.1111/jam.13351

PUEL, O., GALTIER, P., OSWALD, I. 2010. Biosynthesis and toxicological effects of patulin. Toxins, 2(4), 613-631. https://doi.org/10.3390/toxins2040613 ROUSSEAUX, S., DIGUTA, C. F., RADOÏ-MATEI, F., ALEXANDRE, H., GUILLOUX-BENATIER, M. 2014. Non-Botrytis grape-rotting fungi responsible for earthy and moldy off flavors and mycotoxins. Food Microbiol, 38, 104-121. https://doi.org/10.1016/j.fm.2013.08.013

RUSSELL, R., PATERSON, M., VENÂNCIO, A., LIMA, N., GUILLOUXBÉNATIER, M., ROUSSEAUX, S. 2018. Predominant mycotoxins, mycotoxigenic fungi and climate change related to wine. Food Research International, 103, 478-491. https://doi.org/10.1016/i.foodres.2017.09.080

SAMSON, R. A., FRISVAD, J. C. 2004. Polyphasic taxonomy of Penicillium subgenus Penicillium: new taxonomic schemes, mycotoxins and other extrolites.
In Studies in Mycology 46, Utrecht, The Netherlands : Centraalbureau voor Schimmelcultures, 260 p. ISBN 90-70351-53-6.

SAMSON, R. A., HOEKSTRA, E. S., FRISVAD, J. C., FILTENBORG, O 2002a. Introduction to food- and airborne fungi. Utrecht : Centraalbureau voor Schimmelcultures, $\quad 389 \quad \mathrm{p} \quad$ ISBN $\quad 90-70351-42-0$ http://dx.doi.org/10.1007/s11046-005-4201-1

SAMSON, R. A., HOEKSTRA, E. S., LUND, F., FILTENBORG, O., FRISVAD, J. C. 2002b. Method for the detection, isolation and characterisation of food-borne fungi. In Samson, R. A., Hoekstra, E. S., Frisvad, J. C. \& Filtenborg, O. Introduction to food- and airborne fungi. Utrecht : Centraalbureau voor Schimmecultures, p. 283-297. ISBN 90-70351-42-0. http://dx.doi.org/10.1007/s11046-005-4201-1

SAMSON, R. A., HOUBRAKEN, J., THRANE, U., FRISVAD, J. C. ANDERSEN, B. 2010. Food and Indoor Fungi. Utrecht : CBS - KNAW Fungal Biodiversity Centre, 390 p. ISBN 978-90-70351-82-3.

SAMSON, R. A., PETERSON, S. W., FRISVAD, J. C., VARGA, J. 2011. New species in Aspergillus section Terrei. Studies in Mycology, 69, 39-55. https://doi.org/10.3114/sim.2011.69.04

SERRA, R., BRAGA, A., VENÂNCIO, A. 2005. Mycotoxin-producing and other fungi isolated from grapes for wine production, with particular emphasis on ochratoxin A. Res Microbiol., 156(4), 515-521. https://doi.org/10.1016/j.resmic.2004.12.005

SERRA, R., LOURENCCO, A., ALIPIO, P., VENÂNCIO, A. 2006. Influence of the region of origin on the mycobiota of grapes with emphasis on Aspergillus and Penicillium species. Mycological Research, 110(8), 971-978. https://doi.org/10.1016/j.mycres.2006.05.010

STEEL, C. C., BLACKMAN, J. W., SCHMIDTKE, M. 2013. Grapevine bunch rots: Impacts on wine composition, quality and potential procedures for the removal of wine faults. J Agric Food Chem, 61(22), 5189- 5206 https://doi.org/10.1021/jf400641r

TANČINOVÁ, D., RYBÁRIK, L., MAŠKOVÁ, Z., FELŠÖCIOVÁ, S., CÍSAROVÁ, M. 2015. Endogenal colonization of grapes berries. J Microbiol Biotech Food Sci, 4, 69-73. https://doi.org/10.15414/jmbfs.2015.4.special1.69-73 TRINIDAD, A. V., GANOZA, F. Q., PINTO, V. F., PATRIARCA, A. 2015 Determination of mycotoxin profiles characteristic of Alternaria strains isolated from Malbec grapes. BIO Web of Conferences 5, p. 02004. EDP Sciences. http://dx.doi.org/10.1051/bioconf/20150502004

ÚKSÚP, 2019a. Home page address: http://www.uksup.sk/ovv-informacie ÚKSÚP, 2019b. Home page address: http://www.uksup.sk/vinohradnicke-oblasti VARGA, J., KOZAKIEWICZ, Z. 2006. Ochratoxin A in grapes and grapederived products. Trends in Food Science and Technology, 17(2), 72-81 https://doi.org/10.1016/j.tifs.2005.10.007

VARGA, V., KOCSUBÉ, S., SZIGETI, G., BARANYI, N., TÓTH, B. 2015. Aspergillus mycotoxins. In PATERSON, R. R. M., LIMA, N. (Eds.), Molecular biology of food and water borne mycotoxigenic and mycotic fungi. Baton Rouge : CRC Press, 165-186. https://doi.org/10.1201/b18645-17

VISAGIE, C. M., HOUBRAKEN, J., FRISVAD, J. C., HONG, S. B., KLAASSEN, C. H. W., PERRONE, G., SEIFERT, K. A., VARGA, J., YAGUCHI, T., SAMSON, R. A. 2014. Identification and nomenclature of the genus Penicillium. Stud. Mycol., 78, 343-371. https://doi.org/10.1016/j.simyco.2014.09.001

VISAGIE, C. M., HOUBRAKEN, J., RODRIQUES, C., SILVA PEREIRA, C., DIJKSTERHUIS, J., SEIFERT, K. A., JACOBS, K., SAMSON, R. A. 2013. Five new Penicillium species in section Sclerotiora: a tribute to the Dutch Royal family. Persoonia - Molecular Phylogeny and Evolution of Fungi, 31(1), 42-62. https://doi.org/10.3767/003158513x667410

ZHANG, X., LI, Y., WANG, H., GU, X., ZHENG, X., WANG, Y. 2016. Screening and identification of novel ochratoxin a-producing fungi from grapes. Toxins, 8(11), 1-14. https://doi.org/10.3390/toxins8110333 